\title{
ANALISIS MANAJEMEN KEUANGAN DESA DALAM MENINGKATKAN EFEKTIFITAS PELAKSANAAN PROGRAM PEMBANGUNAN DI DESA TASSESE KABUPATEN GOWA
}

\author{
firmansyah \\ firman.syah@unismuh.ac.id \\ Fakultas Ekonomi dan Bisnis \\ Universitas Muhammadiyah Makassar \\ Aulia \\ aulia@gmail.com \\ Fakultas Ekonomi dan Bisnis \\ Universitas Muhammadiyah Makassar
}

\begin{abstract}
This study aims to determine and analyze Village Financial Management in Increasing the Effectiveness of the Implementation of Development Programs in Tassese Village, Gowa Regency. This type of research used a quantitative descriptive approach. The data used are village income budget in 2016, 2017,2018. The calculation technique used in the study is the effectiveness ratio analysis. The results of the analysis though the calculation of the 2016 PAD effectiveness ratio income by $29 \%$ then the income is said to be ineffective and in 2017 the amount of revenue increased by $100 \%$ then the income is said to be effective, while in 2018 the amount of revenue decreased by 99\% then the income is said to be quite effective. Financial analysis using the effectiveness fluctuation of PAD. Thus, it can be said that financial management through the effectiveness ratio helps planning and implementing development programs.
\end{abstract}

Key words : Financial management, Effectiveness ratio,Village development

\begin{abstract}
Abstrak
Penelitian ini bertujuan untuk mengetahui dan menganalisis Manajemen Keuangan Desa dalam Meningkatkan Efektifitas Pelaksanaan Program Pembangunan di Desa Tassese Kabupaten Gowa. Jenis penelitian yang digunakan pendekatan deskriptif kuantitatif. Data yang digunakan yaitu anggaran pendapatan desa tahun 2016, 2017, 2018. Teknik perhitungan yang digunakan dalam penelitian adalah analisis rasio efektifitas. Hasil analisis melalui perhitungan rasio efektifitas PAD Tahun 2016 pendapatan sebanyak 29\% maka pendapatan dikatakan tidak efektif dan pada Tahun 2017 jumlah pendapatan meningkat yaitu 100\% makan pendapatan dikatakan efektif, sedangkan pada Tahun 2018 jumlah pendapatan menurun yaitu 99\% maka pendapatan dikatakan cukup efektif. Analisis keuangan menggunakan formulasi analisis rasio efektifitas dapat memperlihatkan fluktuasi efektifitas dari PAD. Sehingga, hal tersebut dapat dikatakan bahwa manajemen keuangan melalui rasio efektifitas membantu perencanaan dan pelaksanaan program pembangunan.
\end{abstract}

Kata Kunci: Manajemen Keuangan, Rasio Efektifitas, Pembangunan Desa 


\section{PENDAHULUAN}

Untuk mendorong kesatuan ekonomi maka pemerintah diharapkan mampu menetapkan program pemerataan pembangunan berskala nasional yang mencakup semua wilayah. Seperti diketahui bahwa saat ini pembangunan nasional disokong oleh unsur-unsur pembangunan daerah atau lebih dikenal dengan membangun Indonesia dari desa, karena kamajuan desa sangat mempengaruhi kemajuan perekonomian di Indonesia.

Era reformasi, demokratisasi, dan otonomi daerah memberikan ruang yang luas pada daerah untuk terus berkembang dan memanfaatkan potensi wilayah untuk memakmurkan masyarakatnya. Pembangunan merupakan suatu proses perubahan kearah yang lebih baik melalui upaya yang dilakukan secara terencana. Perubahan yang mencakup seluruh system sosial, seperti politik, ekonomi, infrastruktur, pertahanan, Pendidikan dan teknologi, kelembagaan dan budaya. Berbicara masalah pembangunan tidak terlepas dari pembangunan infrastruktur, yang mana secara umum dapat dikatakan bahwa pembangunan infrastruktur merupakan syarat perlu dalam pembangunan.

\section{Pembangunan}

infrastruktur merupakan salah satu aspek penting dan vital untuk mempercepat proses pembangunan nasional. Infrastruktur juga memegang peranan penting sebagai salah satu roda penggerak pertumbuhan ekonomi. Ini mengingat gerak laju dan pertumbuhan ekonomi suatu negara tidak dapat pisahkan dari ketersediaan infrastruktur seperti transportasi, telekomunikasi dan energi. Oleh karena itu, pembangunan sektor ini menjadi fondasi dari pembangunan ekonomi selanjutnya.
Maka arah kebijakan pemerintah dalam pembangunan daerah dapat dilihat pada salah satu poin arah kebijakan adalah menciptakan pemerataan pertumbuhan ekonomi termasuk kemandirian sosial dan ekonomi dengan memanfaatkan potensi wilayah secara optimal dan mendorong usaha-usaha untuk mengurangi ketergantungan pada sumber daya yang tidak dapat diperbaharui kepada sumber daya alam yang dapat diperbaharui menuju masyarakat yang berkualitas, maju, dan mandiri dalam keanekaragaman penduduk dan kegiatanya.

Undang-Undang Nomor 6 Tahun 2014 Tentang Desa menjelaskan bahwa Desa pada Tahun 2015 akan mendapatkan kucuran dana sebesar $10 \%$ dari Anggaran Pendapatan dan Belanja Negara (APBN). Dana yang masuk ke Desa tersebut dinamakan Dana Desa. Sesuai dengan Peraturan Pemerintah Nomor 60 Tahun 2014 Tentang Dana Desa yang bersumber dari Anggaran Pendapatan dan Belanja Negara sebagaimana telah beberapa kali diubah.

Terakhir dengan Peraturan Pemerintah Nomor 8 Tahun 2016 Tentang Perubahan Kedua Atas Peraturan Pemerintah Nomor 60 Tahun 2014 Tentang Dana Desa yang Bersumber dari Anggaran Pendapatan dan Belanja Negara pada Pasal 1 angka (2) disebutkan bahwa Dana Desa adalah dana yang bersumber dari Anggaran Pendapatan dan Belanja Negara yang diperuntunkan bagi Desa yang ditransfer melalui Anggaran Pendapatan dan Belanja Daerah kabupaten/ kota dan digunakan untuk membiayai penyelenggaraan pemerintahan, pelaksanaan pembangunan, pembinaan kemasyarakatan, dan pemberdayaan masyarakat. 
Pengelolaan keuangan Desa tentunya harus dilakukan dengan manajemen yang baik dan akuntabel karena dana yang masuk ke Desa bukanlah dana yang kecil, melainkan sangat besar untuk dikelola oleh sebuah pemerintahan Desa. Dengan adanya kebijakan dana Desa tersebut, maka dimensi manajemen pada kebijakan pelaksanaan Dana Desa tersebut perlu untuk diterapkan dengan baik karena menurut Nugroho (2014) kebijakan publik di dalamnya terjadi proses perancangan dan perencanaan, pelaksanaan melalui berbagai organisasi dan kelembagaan, serta untuk mencapai hasil yang optimal, maka implementasi kebijakan publik harus dikendalikan. Dari pemaparan ahli tersebut jelas bahwa implementasi kebijakan yang baik di dalamnya dipengaruhi oleh proses manajemen yang baik pula untuk mencapai sesuatu yang diharapkan ketika pelaksaan sudah berjalan.

Selanjutnya, Ramdhani dan Ramdhani (2017) menyatakan bahwa pelaksanaan kebijakan adalah implementasi atau penerapan suatu kebijakan melalui program, aktifitas, aksi, atau tindakan dalam suatu mekanisme yang terikat pada suatu system tertentu. Dana Desa merupakan kebijakan yang baru bagi Desa itu sendiri, banyak kalangan yang meragukan keberhasilan dari kebijakan ini karena ketidaksiapan dari Aparatur Pemerintah Desa itu sendiri, terutama dalam pengelolaan keuangan yang business process-nya hampir sama dengan tingkat Pemerintah Daerah. Padahal menurut Edward III (dalam Nugroho, 2014) bahwa ketersediaan sumberdaya pendukung, khususnya Sumber Daya Manusia (SDM) yang cakap menjadi faktor untuk carry out kebijakan public yang efektif.

Menurut John. P (2015) pun berpendapat bahwa lemahnya sumberdaya menjadi salah satu faktor implementasi kebijakan tidak efektif dan tidak tepat sasaran yang mengakibatkan pelaksanaan pembangunan tidak berjalan dengan semestinya. Efektifitas pada dasarnya menunjukan kepada suatu ukuran tingkat kesesuaian antara hasil yang dicapai dengan hasil yang diharapkan sebagaimana telah terlebih dahulu ditetapkan (Iskandar,2016) melalui dokumen perencanaan pembangunan Desa.

Dapat dipahami bahwa tugas utama manajemen adalah suatu efektifitas itu sendiri (Iskandar, 2016) sehingga penyusunan Rencana Pembangunan Jangka Menengah Desa (RPJMDesa) dan Rencana Kerja Pemerintah Desa (RKPDesa) akan mempengaruhi efektif tidaknya program pembangunan Desa. Pada umumnya Untuk mengukur keberhasilan suatu pemerintah Desa berdasarkan dari kinerjanya. Misalnya program pembangunan di Desa berjalan efektif atau sebaliknya, dapat dinilai melalui laporan keuangan yang disajikan secara teratur setiap periode. Informasi akuntansi dalam laporan keuangan sangat penting bagi pemerintah. Agar bermanfaat informasi harus relevan, informasi dikatakan relevan jika dapat mempengaruhi keputusan dalam mengevaluasi peristiwa masa lalu, masa kini, atau masa yang akan datang, menegaskan atau mengkoreksi hasil evaluasi mereka dimasa lalu.

Pemerintah Desa harus memiliki pengelolaan aktivitas secara efektif dan efisien untuk pencapaian tujuan, hal ini merupakan persyaratan utama untuk dapat melakukan pelayanan publik yang efektif dan untuk memantau perkembangan suatu aktifitas pemerintah Desa. Untuk memantau perkembangan aktifitas suatu pemerintah Desa yaitu dengan melihat manajemen keuangannya. Menurut Sutrisno (2000:3) manajemen keuangan dapat diartikan 
sebagai semua aktivitas perusahaan yang berhubungan dengan usaha-usaha mendapatkan dana dengan biaya yang murah serta usaha untuk menggunakan dan mengalokasikan dana tersebut secara efisiensi. Sedangkan menurut Martono dan Hartijo (2005:16) menyatakan bahwa manajemen keuangan atau yang sering pula disebut dengan istilah pembelanjaan adalah seluruh aktivitas perusahaan dalam rangka memperoleh dana, menggunakan dana dan mengelola asset.

Syamsuddin (2007:3) mendefinisikan manajemen keuangan merupakan penerapan prinsip-prinsip ekonomi dalam mengelolah keputusan-keputusan yang menyangkut masalah financial perusahaan. Pengertian manajemen keuangan desa (menurut Undang-undang Nomor 6 Tahun 2014 Pasal 71 ayat 1), adalah semua hak dan kewajiban desa yang dapat dinilai dengan uang serta segala sesuatu baik berupa uang maupun barang yang berhubungan dengan pelaksanaan hak dan kewajiban desa. pengelolaan keuangan desa adalah keseluruhan kegiatan yang meliputi perencanaan, pelaksanaan, penatausahaan, pelaporan dan pertanggungjawaban keuangan desa.

Dalam Permen Nomor 113 Tahun 2014 tentang pengelolaan keuangan desa, keuangan desa dikelola berdasarkan asasasas transparan, akuntabel, partisipatif serta dilakukan dengan tertib dan disiplin anggaran. Pengelolaan keuangan desa dikelola dalam masa 1 (satu) tahun anggaran yakni mulai tanggal 1 Januari sampai dengan 31 Desember. Manajemen keuangan Desa berupa laporan keuangan yaitu anggaran pendapatan dan belanja Desa dibuat sesuai dengan aturan yang berlaku sehingga mudah dipahami oleh berbagai pihak yang berkepentingan.
Untuk menunjukkan kondisi dan posisi keuangan yang sesungguhnya. Karena laporan keuangan merupakan cerminan dari prestasi manajemen pada satu periode tertentu, dan untuk mengetahui efektiftifitas pelaksanaan program pembangunan di Desa terlaksana dengan efektif atau sebaliknya, yang mengakibatkan pelaksanaan pembangunan tidak berjalan dengan semestinya. Efektifitas pada dasarnya menunjukan kepada suatu ukuran tingkat kesesuaian antara hasil yang dicapai dengan hasil yang diharapkan. Untuk mengetahui efektif atau tidak efektifnya suatu aktifitas pembangunan suatu pemerintah Desa dilihat dari manajemen keuangannya telah dikembangkan seperangkat teknik analisis yang didasarkan pada laporan keuangan yang dipublikasikan.

Salah satu teknik tersebut yaitu rasio efektifitas PAD. Rasio efektifitas PAD menggambarkan kemampuan pemerintah desa dalam merealisasikan PAD yang direncanakan dibandingkan dengan target yang ditetapkan berdasarkan potensi rill desa. Semakin tinggi rasio efektifitas PAD maka semakin efektif program pembangunan pemerintah desa. Dilihat dari kriteria tingkat efektifitas penerimaan PAD sesuai dengan Keputusan Menteri Dalam Negeri No. 690.900-327 Tahun 1996, kriteria tingkat efektifitas penerimaan PAD sebagai berikut: 1) Jika hasil perbandingan lebih dari $100 \%$, maka pendapatan dikatakan sangat efektif 2)Jika hasil pencapaian 100\% maka pendapatan dikatakan efektif 3) Jika hasil pencapaian antara 90\%-99\%, maka pendapatan dikatakan cukup efektif 4) Jika hasil pencapaian 75\%-89\%, maka pendapatan dikatakan kurang efektif. 5) Jika hasil pencapaian dibawah 75\%, maka pendapatan dikatakan tidak efektif. 
Penelitian ini dimaksudkan untuk melakukan pengujian lebih lanjut temuantemuan empiris mengenai rasio efektifitas PAD berdasarkan manajemen keuangannya dalam meningkatkan efektifitas pelaksanaan program pembangunan di Desa. Penggunaan analisis Rasio efektifitas PAD diharapkan mampu menggambarkan kemampuan pemerintah desa dalam merealisasikan PAD yang direncanakan dibandingkan dengan target yang ditetapkan berdasarkan potensi rill desa. Apakah berjalan efektif atau sebaliknya, Karena semakin tinggi rasio efektifitas PAD maka semakin efektif program pembangunan pemerintah desa.

Dilihat dari kriteria tingkat efektifitas penerimaan PAD sesuai dengan Keputusan Menteri Dalam Negeri No. 690.900-327 Tahun 1996. Dengan menganalisis manajemen keuangan Desa dengan teknik analisis rasio efektifitas PAD diharapkan mampu meningkatkan efektifitas pelaksanaan program pembangunan Desa. Berdasarkan latar belakang tersebut peneliti tertarik untuk melakukan penelitian dengan judul "Analisis Manajemen Keuangan Desa dalam Meningkatkan Efektifitas Pelaksanaan Program Pembangunan di Desa Tassese Kabupaten Gowa".

\section{TINJAUAN PUSTAKA}

\section{a. Manajemen keuangan}

Manajemen Keuangan merupakan suatu proses dalam kegiatan keuangan perusahaan yang berhubungan dengan upaya untuk mendapatkan dana perusahaan serta meminimalkan biaya perusahaan dan juga upaya pengelolaan keuangan suatu badan usaha atau organisasi untuk dapat mencapai suatu tujuan keuangan yang telah ditetapkan.
Menurut Horne dan Wachowicz Jr. (2012:2) dalam bukunya yang berjudul Fundamentals of Financial Management yang telah di alih bahasa menjadi prinsipprinsip manajemen keuangan mengemukakan bahwa manajemen keuangan berkaitan dengan perolehan aset, pendanaan, dan manajemen aset dengan didasari beberapa tujuan umum.

Sutrisno (2000:3) manajemen keuangan dapat diartikan sebagai semua aktivitas perusahaan yang berhubungan dengan usaha-usaha mendapatkan dana dengan biaya yang murah serta usaha untuk menggunakan dan mengalokasikan dana tersebut secara efisiensi. Sedangkan menurut Martono dan Hartijo (2005:16) menyatakan bahwa manajemen keuangan atau yang sering pula disebut dengan istilah pembelanjaan adalah seluruh aktivitas perusahaan dalam rangka memperoleh dana, menggunakan dana dan mengelola asset. Menurut Syamsuddin (2007:3) mendefinisikan manajemen keuangan merupakan penerapan prinsip-prinsip ekonomi dalam mengelolah keputusankeputusan yang menyangkut masalah financial perusahaan.

\section{b. Fungsi dan Tujuan Manajemen Keuangan}

Fungsi manajemen keuangan dalam suatu perusahaan dapat dilihat dari tugas dan tanggung jawab seorang manajer atau direktur keuangan. Tugas dan tanggung jawab manajer keuangan antar perusahaan mungkin saja berbeda. Hal ini mungkin bergantung pada jenis usaha perusahaan, besar kecilnya ukuran perusahaan. Ini berarti tugas dan tanggung jawab manajer keuangan antar perusahaan mungkin saja mempunyai cakupan yang berbeda, tetapi ada beberapa kesamaan yang dapat diidentifikasi. Fungsi manajemen keuangan 
terdiri dari tiga keputusan utama yang harus dilakukan oleh suatu perusahaan, utamanya seorang manajer atau direktur keuangan. Keputusan keuangan ini diimplementasikan dalam kegiatan sehari-hari untuk memperoleh laba. Laba yang diperoleh diharapkan mampu meningkatkan nilai perusahaan yang tercermin pada makin tingginya harga saham, sehingga kemakmuran para pemegang saham dengan sendirinya makin bertambah. Menurut Harmono (2009:18) ada tiga macam fungsi manajemen keuangan yaitu:

1) Keputusan investasi

Keputusan investasi ini menyangkut bagaimana manajer keuangan mengalokasikan dana kedalam bentukbentuk investasi yang akan mendatangkan keuntungan dimasa yang akan datang. Hasil dari kebijakan investasi, secara sederhana dapat dilihat pada sisi aktiva neraca perusahaan.

2) Keputusan pembelanjaan kegiatan usaha Dalam hal ini seorang manajer keuangan dituntut untuk mempertimbangkan dan menganalisis kombinasi sumber-sumber pembelanjaan yang ekonomis bagi perusahaan guna membelanjai kebutuhan-kebutuhan investasi serta kegiatan usahanya. Hasil kebijakan sumber pembelanjaan, secara sederhana dapat dilihat pada sisi passiva neraca perusahaan.

3) Keputusan deviden

Deviden merupakan bagian keuntungan yang dibayarkan oleh perusahaan kepada para pemegang saham. Oleh karena itu dividen ini merupakan bagian dari penghasilan yang diharapkan oleh pemegang saham. Uraian tersebut di atas memberikan indikasi bahwa fungsi pokok pembelanjaan menduduki posisi yang cukup penting dalam suatu perusahaan.
Bersadarkan tujuannya manajemen keuangan terbagi beberapa jenis, yaitu:

1) Maksimalisasi keuntungan

Tujuan utama dari manajemen keuangan adalah untuk maksimalisasi keuntungan. Manajer keuangan mencoba untuk mendapatkan keuntungan yang maksimal bagi perusahaan dalam jangka pendek dan jangka Panjang. Seorang manajer keuangan tidak bisa menjamin keuntungan dalam jangka panjang karena ketidakpastian bisnis. Namun perusahaan dapat memperoleh keuntungan maksimal bahkan dalam jangka panjang, jika manajer keuangan mengambil keputusan keuangan yang tepat dan menggunakan keuangan perusahaan dengan baik.

2) Menjaga arus kas

Menjaga arus kas yang tepat merupakan tujuan jangka pendek manajemen keuangan. Perusahaan harus memiliki arus kas yang tepat untuk membayar biaya sehari-hari seperti pembelian bahan baku, pembayaran upah dan gaji, sewa, tagihan listrik, dan lain-lain. Arus kas yang baik tentunya akan meningkatkan keberhasilan perusahaan.

3) Mempersiapkan struktur modal Tujuan manajemen keuangan yang tidak kalah penting adalahuntuk mempersiapkan struktur modal. Perusahaan harus memutuskan rasio antara pembiayaan yang dimiliki dan keuangan yang dipinjam supaya seimbang. Keseimbangan ini diperlukan untuk likuiditas, ekonomi, fleksibilitas dan stabilitas perusahaan.

4) Pemanfaatan keuangan yang tepat Manajer keuangan harus membuat pemanfaatan keuangan secara optimal pemanfaatan keuangan secara optimal dan perusahaan harus tidak berinvestasi 
keuangan perusahaan dalam proyekproyek yang tidak menguntungkan.

5) Maksimalisasi kekayaan

Maksimalisasi kekayaan berarti untuk mendapatkan kekayaan yang maksimal bagi pemegang saham. Jadi, manajer keuangan mencoba memberikan dividen maksimal kepada pemegang saham. Manajer keuangan juga mencoba untuk meningkatkan nilai pasar saham karena nilai pasar saham secara langsung berhubungan dengan kinerja perusahaan.

6) Meningkatkan efisiensi

Manajemen keuangan juga mencoba untuk meningkatkan efisiensi semua departemen perusahaan. Distribusi keuangan yang tepat untuk semua departemen akan meningkatkan efisiensi seluruh peusahaan.

7) Kelangsungan hidup perusahaan Kelangsungan hidup adalah tujuan yang paling penting dari maanjemen keuangan. Perusahaan harus bertahan hidup didunia bisnis yang kompetitif ini. Manajer keuangan harus sangat berhatihati saat membuat keputusan keuangan. Satu keputusan salah dapat membuat perusahaan merugi dan bangkrut.

8) Mengurangi risiko operasional

Manajemen keuangan juga mencoba untuk mengurangi risiko operasional. ada banyak risiko dan ketidakpastian dalam bisnis. Manajer keuangan harus mengambil langkah-langkah untuk mengurangi risiko ini. Dia harus menghindari proyek berisiko tinggi.

9) Mengurangi biaya modal

Manajemen keuangan adalah untuk mengurangi biaya modal yang artinya perusahaan mencoba untuk bisa meminjam uang pada tingkat bunga yang rendah. Manajer keuangan harus merencanakan struktur modal sedemikian rupa sehingga biaya modal itu diminimalkan.

\section{c. Pengertianmanajemen keuangan desa dan Desa}

1. Pengertian manajemen keuangan desa

Menurut Undang-Undang Nomor 6 Tahun 2014 Pasal 71 (1) manajemen keuangan desa adalah semua hak dan kewajiban desa yang dapat dinilai dengan uang serta segala sesuatu baik berupa uang maupun barang yang berhubungan dengan pelaksanaan hak dan kewajiban desa. pengelolaan keuangan desa adalah keseluruhan kegiatan yang meliputi perencanaan, pelaksanaan, penatausahaan, pelaporan dan pertanggungjawaban keuangan desa. Dalam Permen Nomor 113 Tahun 2014 tentang pengelolaan keuangan desa, keuangan desa dikelola berdasarkan asas-asas transparan, akuntabel, partisipatif serta dilakukan dengan tertib dan disiplin anggaran. Pengelolaan keuangan desa dikelola dalam masa 1 (satu) tahun anggaran yakni mulai tanggal 1 Januari sampai dengan 31 Desember.

\section{Pengertian desa}

Desa adalah bagian yang penting dari suatu masyarakat yang mana tak dapat terpisahkan. Pentingnya desa ini disampaikan oleh berbagai ahli yang memberikan pendapatnya. Oleh karena itulah, keberadaan Desa semestinya tidak boleh diremehkan termasuk juga oleh pemerintah karena pentingnya keberadaan Desa tersebut. Definisi Desa menurut Kamus Besar Bahasa Indonesia atau KBBI, adalah kesatuan wilayah yang dihuni oleh sejumlah keluarga yang mempunyai sistem pemerintahan sendiri (dikepalai oleh seorang Kepala Desa) atau Desa merupakan kelompok rumah di luar kota yang merupakan kesatuan. 
Kata desa sendiri berasal dari bahasa Sansekerta yakni "dhesi" yang berarti tempat lahir. Namun, perlahan artian dari Desa sendiri berkembang baik yang menambah maknanya hingga mengurangi maknanya sehingga memiliki kesan negatif. Padahal, berbagai ahli berpendapat bahwa desa memiliki berbagai peranan penting. Definsi Desa menurut Undang-undang ditambahkan pada Undang-Undang Nomor. 22 Tahun 1999, adalah kesatuan masyarakat hukum yang memiliki kewenangan untuk mengatur dan mengurus kepentingan masyarakat setempat berdasarkan asal usul dan adat istiadat setempat yang diakui dalam sistem pemerintahan Nasional dan berada di daerah Kabupaten.

\section{d. Pengertian Efektifitas}

Secara etimologi kata efektifitas berasal dari kata efektif, dalam bahasa inggris effectiviness yang bermakna berhasil. Menurut kamus besar bahasa indonesia kata efektif berarti pengaruh, akibat atau dapat membawa hasil. Jadi efektifitas adalah daya guna, adanya kesesuaian dalam suatu kegiatan orang yang melaksanakan tugas dengan sasaran yang dituju. Makmur dalam bukunya efektifitas kebijakan kelembagaan pengawasan (2010:7) berpendapat bahwa efektifitas dapat diukur dari beberapa hal yaitu :

1) Ketepatan penentuan waktu: waktu yang digunakan secara tepat akan mempengaruhi tingkat keefektifitasan suatu program atau kegiatan dalam mencapai tujuan.

2) Ketepatan perhitungan biaya: hal ini dilakukan agar dalam menjalankan suatu program tidak mengalami kekurangan dalam hal dana atau anggaran sampai program tersebut selesai dilaksanakan.

3) Ketepatan dalam pengukuran: hal ini berarti bahwa dalam menjalankan suatu program harus menerapkan standarisasi. Ketepatan standar yang digunakan dalam melaksanakan suatu program merupakan suatu ukuran dalam mencapai keefektifitasan.

4) Ketepatan dalam menentukan pilihan merupakan suatu kegiatan yang dilakukan untuk keberhasilan dalam mencapai tujuan karna dalam menentukan pilihan dibutuhkan proses yang sangat penting untuk mencapai suatu keefektifitasan.

5) Ketepatan berfikir dapat menentukan efektifitas dalam mencapai tujuan yang telah ditentukan.

6) Ketepatan dalam melakukan perintah merupakan aktivitas organisasi atau individu yang mempunyai kemampuan memberikan perintah dengan jelas dan Mudah dipahami dan jika perintah yang diberikan tidak dapat dipahami maka pelaksanaan perintah tersebut akan mengalami kegagalan dan pada akhirnya efektif.

7) Ketepatan dalam menentukan tujuan tujuan yang ditetapkan secara tepat akan menunjang efektifitas pelaksanaan kegiatan tersebut.

8) Ketepatan sasaran dapat menentukan keberhasilan aktivitas individu atau organisasi dalam mencapai tujuan.

Rasio efektifitas PAD menggambarkan kemampuan pemerintah desa dalam merealisasikan PAD yang direncanakan dibandingkan dengan target yang ditetapkan berdasarkan potensi rill desa. Semakin tinggi rasio efektifitas PAD maka semakin efektif program pembangunan pemerintah desa. Rasio efektifitas PAD dapat dirumuskan sebagia berikut: 
Rasio efektifitas PAD

$$
=\frac{\text { Realisasi PAD }}{\text { Anggaran PAD }} \times 100 \%
$$

Keputusan Menteri Dalam Negeri No. 690.900-327 Tahun 1996, kriteria tingkat efektifitas penerimaan PAD sebagai berikut:

1) Jika hasil perbandingan lebih dari $100 \%$, maka pendapatan dikatakan sangat efektif.

2) Jika hasil pencapaian 100\% maka pendapatan dikatakan efektif

3) Jika hasil pencapaian antara 90\%-99\%, maka pendapatan dikatakan cukup efektif.

\section{METODE PENELITIAN}

\section{a. Jenis Penelitian}

Penelitian ini menggunakan pendekatan dekskriptif kuantitatif. Data yang dikumpulkan semata-mata bersifat deskriptif sehingga tidak bermaksud untuk mencari penjelasan, menguji hipotesis, membuat prediksi ataupun mencari implikasi. Dengan kata lain, penelitian deskriptif menekankan pada penyajian data secara sistematis dan akurat sehingga dapat memberikan gambaran dengan jelas.

\section{b. Populasi dan Sampel \\ 1) Populasi}

Menurut Sugiyono (1997 : 57) memberikan pengertian bahwa : "Populasi adalah wilayah generalisasi yang terdiri dari obyek atau subyek yang menjadi kuantitas dan karakteristik tertentu yang ditetapkan oleh peneliti untuk dipelajari dan kemudian ditarik kesimpulannya. Populasi adalah wilayah generalisasi yang terdiri dari atas objek atau subjek yang ditetapkan oleh peneliti untuk dipelajari dan kemudian ditarik kesimpulannya.

Populasi data yang diambil dalam penelitian ini adalah laporan keuangan sebagai landasan pokok untuk mengetahui analisis manejemen keuangan desa dalam meningkatkan efektifitas pelaksanaan program pembangunan desa tiga tahun terakhir yaitu tahun 2016, 2017, 2018 Pada kantor desa Tassese, Kabupaten Gowa.

\section{2) Sampel}

Menurut Sugiyono (2008: 118) menjelaskan bahwa sampel memiliki arti suatu bagian dari keseluruhan serta karakteristik yang dimiliki oleh sebuah populasi. Adapun sampel yang dibutuhkan dalam penelitian ini adalah laporan keuangan berupa anggaran pendapatan desa Tassese kabupaten Gowa Tahun 2016, 2017, 2018.

\section{c. Teknik Pengumpulan Data}

Teknik pengumpulan data yang digunakan penelitian ini dalah sebagai berikut:

1) Penelitian pustaka (Library research), yaitu peneliti mengumpulkan data yang berh

2) ubungan dengan teori tentang manejemen keuangan dalam meningkatkan efektifitas pembangunan Desa. Pada kantor Desa Tassese, Kabupaten Gowa.

3) Penelitian lapang (field research), yaitu kegiatan penelitian lapangan, dimana peneliti mencari data yang menjadi obyek penelitian, untuk memperoleh data peneliti melakukan pengamatan setempat dan diskusi langsung dengan kepala desa serta beberapa staf desa dan mengumpulkan informasi yang diperlukan. Untuk hal tersebut maka peneliti mengadakan:

a) Observasi, yaitu dengan cara melakukan pengamatan langsung di lapangan untuk mendapatkan data yang menyangkut kondisi dan posisi kantor, struktur organisasi, dan sejarah Kantor Desa Tassese. 
b) Wawancara, yaitu peneliti mengadakan tanya jawab dengan kepala desa dan staf desa, untuk mendapatkan data tentang laporan keuangan kantor desa, dan informasi yang berhubungan dengan topik dari masalah penelitian.

\section{d. Teknik Analisis Data}

Teknik analisis data merupakan teknik yang digunakan untuk mengolah dan memprediksi hasil penelitian guna memperoleh suatu kesimpulan. Berdasarkan judul, latar belakang, dan perumusan masalah maka teknik analisis yang digunakan adalah teknik analisis kuantitatif deskriptif, dengan menggunakan analisis rasio efektifitas PAD.

Sugiono (2010:147) menyatakan bahwa analisis deskriptif adalah statistik yang digunakan untuk menganalisis data dengan cara mendeskripsikan atau menggambarkan data yang telah terkumpul sebagaimana adanya tanpa bermaksud membuat kesimpulan yang berlaku untuk umum atau generalisasi.

1) Rasio Efektifitas

$$
\text { Rasio efektifitas PAD }
$$

menggambarkan kemampuan pemerintah desa dalam merealisasikan PAD yang direncanakan dibandingkan dengan target yang ditetapkan berdasarkan potensi rill desa. Semakin tinggi rasio efektifitas PAD maka semakin efektif program pembangunan pemerintah desa. Rasio efektifitas PAD dapat dirumuskan sebagai berikut:

\section{Rasio efektifitas PAD}

$$
=\frac{\text { Realisasi PAD }}{\text { Anggaran PAD }} \times 100 \%
$$

Keputusan Menteri Dalam Negeri No. 690.900-327 Tahun 1996, kriteria tingkat efektifitas penerimaan PAD sebagai berikut:

a) Jika hasil perbandingan lebih dari $100 \%$, maka pendapatan dikatakan sangat efektif.

b) Jika hasil pencapaian 100\% maka pendapatan dikatakan efektif

c) Jika hasil pencapaian antara 90\%-99\%, maka pendapatan dikatakan cukup efektif

d) Jika hasil pencapaian 75\%-89\%, maka pendapatan dikatakan kurang efektif.

e) Jika hasil pencapaian dibawah 75\%, maka pendapatan dikatakan tidak efektif.

\section{HASIL DAN PEMBAHASAN}

Hasil dari perhitungan rasio efektifitas dihitung dari manajemen keuangan desa berupa anggaran pendapatan Tahun Anggaran 2016, Anggaran Pendapatan sebesar Rp. 1.229.306.531,00 dan Realisasi Pendapatan sebesar RP. 1.229.667.574,00 Selisih antara anggaran dan realisasi sebanyak 29,36\% dengan demikian diperoleh rasio efektifitas sebanyak 29\% dikategorikan tidak efektif. pada Tahun Anggaran 2017 Anggaran Pendapatan sebesar Rp. 1.517.275.623,00 dan Realisasi Pendapatan sebesar Rp. 1.517.519.707,00.

Selisih antara anggaran dan realisasi sebanyak 99,65\% dengan diperoleh rasio efektifitas sebanyak 100\% dikategorikan efektif, sedangkan tahun 2018 Anggaran Pendapatan sebesar Rp. 2.019.041.003,00 dan Realisasi Pendapatan sebesar Rp. 1.997.048.199,00 selisih antara anggaran dan realisasi sebanyak 98,91\% dengan demikian diperoleh rasio efektifitas sebanyak 99\% dikategorikan cukup efektif. Jika dilihat dari Hasil analisis perhitungan rasio efektifitas dihitung dari manajemen keuangan Desa berupa anggaran pendapatan yaitu Tahun 2016 sebanyak 29\% maka pendapatan dikatakan tidak efektif, 
dan pada tahun 2017 jumlah pendapatan meningkat yaitu 100\% maka pendapatan dikatakan efektif, sedangkan pada tahun 2018 pendapatan menurun yaitu 99\% maka pendapatan dikatakan cukup efektif. Analisis keuangan menggunakan formulasi analisis rasio efektifitas dapat memperlihatkan fluktuasi efektifitas dari PAD. Sehingga, hal tersebut dapat dikatakan bahwa manajemen keuangan melalui rasio efektifitas membantu perencanaan dan pelaksanaan program pembangunan.

\section{DAFTAR PUSTAKA}

Anwar, K,R. 2011. Analisis Kinerja Keuangan. Skripsi Universitas Hasanuddin Makassar.

Ahmadi. 2001.IImu Pendidikan. Rineka Cipta. Jakarta.

Azwar, 2017. Tentang " Implementasi Kebijakan Pengelolaan Dana Desa di Desa Siboang Kecamatan Sojol Kabupaten Donggala", Jurnal Katalogis, Vol. 5 No.12 ISSN 23022019.

Elisabeth Permatasari, Sapanah, dan Khajanah Hasan, 2018. Tentang "Pengelolaan Alokasi Dana Desa dalam Meningkatkan Pembangunan dan Pemberdayaan Masyarakat Desa, Converence On Innovation and Application of Science and Technology (CIASTECH 2018)" Universitas Widyagama Malang, 12 September 2018, ISSN 2622-1284.

Ghozali, Iman. 2001. Aplikasi Analisis Multivariate dengan Program SPSS. Universitas Diponegoro. Semarang

Herlianto, Didit. 2017. Manajemen Keuangan Desa. Gosyen Publishing Yogyakarta.
Harmono, 2009. Manajemen Keuangan. Cetakan Pertama, Penerbit Bumi Aksara, Yogyakarta.

Husnan, Suad. 1994. Dasar-dasar Manajemen Keuangan. Yogyakarta: UPP AMP YKPN.

Indiantoro, Nur dan Bambang, Supomo. 2002. Metodologi Penelitian Bisnis untuk Akuntansi Manajemen. BPFE. Yogyakarta.

Ismail, M, Ari Kuncara Widagdo, dan Agus Widodo. 2016. "Sistem Akuntansi Pengelolaan Dana Desa". Jurnal Ekonomi dan Bisnis. Vol.XIX No.2, ISSN 1979-6471.

Murba. 2017. Studi Implementasi Program Pembangunan Infrastruktur. Skripsi Universitas Islam Negeri Alauddin Makassar.

Martono, dan Harjito, D.Agus. 2005. Manajemen Keuangan. Edisi Pertama Cetakan Kelima, EKONISIA, Yogyakarta.

Makmur, 2010. Efektivitas Kebijakan Kelembagaan Pengawasan. Refika Aditama. Bandung.

Nugroho, Riant. 2014. Public Policy. Jakarta: PT. Elex Media Komputindo

Pitri, Savarita. 2018. Analisis Manajemen Dana Desa Terhadap Pembangunan Desa .Skripsi Universitas Islam Negeri Raden Intan Lampung.

Ramdhani, A., \& Ramdhani, M. A. 2017. Konsep Umum Pelaksanaan Kebijakan Publik. Jurnal Publik, 11 (February), 112.

Sutrisno. 2000. Manajemen Keuangan Moderen. Bumi Aksara. Jakarta.

Syamsuddin, Lukman. 2007. Manajemen Keuangan Perusahaan Konsep Aplikasi dalam Perencanaan, Pengawasan dan 
Pengambilan Keputusan. (Edisi Baru). PT. Raja Grafindo. Jakarta.

Suparno, 2001. Membangun Kompetensi Belajar. Direktorat Jendral Pendidikan Tinggi. Departemen Pendidikan Nasional.

Santoso, Singgih. 2000. Buku Latihan SPSS Statistik Parametrik. PT. ELEK Media Komputindo. Jakarta.

Suherman, A. 2018. Tentang" Laporan Keuangan Sebagai Perwujudan Transparasi dan Akuntabilitas Pemerintahan Desa, Jurnal IImiah IImu Ekonomi, Vol.6, ISSN 2088-6969.

Sukanto, A, 2014. Tentang "Efektivitas Alokasi Dana Desa (ADD) dan Kemiskinan di Provinsi Sumatera Selatan:", Jurnal Ekonomi Pembangunan, Vol.12 No.1, ISSN 1829-5843.

Suhardi, 2015. "Pemahaman Manajemen Pedesaan pada Perangkat Desa di Wilayah Kecamatan Semen Kabupaten Kediri". Nusantara Of Research Vol.2 No.1, ISSN 2355-7249.

Sulistiyoningtyas, L. 2017. "Pengaruh Alokasi Dana Desa dan Pendapatan Asli Desa Terhadap Belanja Desa di Kecamatan Baron",Jurnal Ekonomi-Akuntansi, Vol.1, No.3 ISSN BBBB-BBBB.

Setiana, N.D dan Yuliani, N.L. 2017. Pengaruh Pemahaman dan Peran Perangkat Desa terhadap Akuntabilitas Pengelolaan Dana Desa. Universitas Muhammadiyah Magelang, ISSN 2407-9189.

Sumarsono. 2010. Menejemen Keuangan Pemerintah. Yogyakarta: Graha IImu.

Sugiyono. 1997. Metodologi Penelitian Administrasi. Yogyakarta: CV Alfabeta.
Sugiyono, 2008. Metode Penelitian Kuantitatif Kualitatif dan R\&D. Bandung: ALFABETA

Tangkumahat, F.V, Panelewen V.V.J, dan Mirah A.D.P. 2017. Dampak Program Dana Desa terhadap Peningkatan Pembangunan dan Ekonomi di Kecamatan Pineleng Kabupaten Minahasa. Jurnal Agri Sosio Ekonomi, Vol.13 No.2a, ISSN 1907-4298.

Yanhar Jamaluddin, Asep Sumaryana, Budiman Rusli dan RD. Ahmad Buchari, 2018. Tentang "Analisis Dampak Pengelolaan dan Penggunaan Dana Desa terhadap Pembangunan Daerah", Jurnal IImu Pemerintahan dan Sosial Politik UMA, ISSN 2550-1305.

Undang- Undang Nomor 6 Tahun 2014 Tentang Desa, Lembaran Negara

Peraturan Pemerintah Nomor 8 tahun 2016 tentang Perubahan atas Peraturan Pemerintah Nomor 60 Tahun 2014 Tentang Dana Desa yang Bersumber dari Anggaran Pendapatan dan Belanja Negara.

Peraturan Menteri Dalam Negeri Republik Indonesia Nomor 113 Tahun 2014 Tentang Pengelolaan Keuangan Desa.

Depdagri. 1997. Kepmedagri
No.690.900.327, 1996, Tentang
Pedoman Penilaian dan Kinerja
Keuangan.
Undang-Undang Nomor. 22 Tahun 1999
tentang Pemerintah Daerah
Undang-Undang Nomor 25 Tahun 2004
tentang Sistem
Pembangunan

https://www. materiakuntansi.com 